Supporting information

\title{
Theoretical Insights into the Key Role of Ru in the Propylene Epoxidation over $\mathrm{Cu}_{2} \mathrm{O}(111)$
}

\begin{abstract}
Rui-Shi Li, Tian-Tian Xiao, Gui-Chang Wang*
(Key Laboratory of Advanced Energy Materials Chemistry (Ministry of Education) and the Tianjin key Lab and Molecule-based Material Chemistry, College of Chemistry, Nankai University, Tianjin 300071, China)

*Corresponding author: Gui-Chang Wang. E-mail: wangguichang@nankai.edu.cn
\end{abstract}

Telephone: +86-22-23503824 (O) Fax: +86-22-23502458 


\section{Contents:}

\section{Calculation methods and surface models}

1.1. Calculation Methods. Periodic slab calculations were carried out by ab initio method based on the first principle of DFT and using the Vienna ab initio simulation package (VASP) $)^{1,2}$ code. The Perdew-BurkeErnzerhof $(\mathrm{PBE})^{3,4}$ generalized gradient approximation (GGA) was used to describe the exchange-correlation functional, and the projector augmented wave (PAW) potentials ${ }^{5-7}$ were used for electron-ion interactions. The electronic wave functions were expanded using a plane wave basis with the cutoff energy of $400 \mathrm{eV}$. The Brillouin zone sampling was conducted using the Monkhorst-Pack scheme, ${ }^{8,9}$ and the k-points were set as $1 \mathrm{x}$ $1 \times 1$ because its result was similar to the $3 \times 3 \times 1$ k-points at the geometry optimizations and there was almost no difference with the continued increase of k-points. In order to analyze the electron correlations in transition metal oxides, we adopted the DFT + U method, ${ }^{10-12}$ and the U-J value was set as $4.0 \mathrm{eV}$ for the $\mathrm{Cu} 3 \mathrm{~d}$ states, which was determined from electrostatically embedded Hartree-Fock calculations ${ }^{13}$ using the method developed by Mosey et al. ${ }^{14}$ In the geometry optimizations, self-consistent field computations were repeated until the sum of forces acted on the relaxed atoms was below $0.05 \mathrm{eV}^{-1}$. The climbing image nudged elastic band (CI-NEB) method $^{15}$ was used to find the transition states (TSs), which were confirmed by the frequency analysis subsequently. The long-range dispersion (van der Waals) interactions was considered by DFT-D3 method. ${ }^{16}$

Besides, we get the adsorption energies ( $E_{\text {ads }}$ ) according to the following formula: $E_{\text {ads }}=E_{\mathrm{A} / \text { slab }}-\left(E_{\text {slab }}+E_{\mathrm{A}}\right)$, where $E_{\mathrm{A} / \text { slab }}, E_{\text {slab }}$, and $E_{\mathrm{A}}$ are the energies of the system of the adsorbate and substrates, the substrate, the adsorbate in gas, respectively. The more negative the value of $E_{\text {ads }}$, the stronger the adsorption. The activation energy $\left(E_{\mathrm{a}}\right)$ and the reaction energy $(\Delta E)$ are defined as $E_{\mathrm{a}}=E_{\mathrm{TS}}-E_{\mathrm{IS}}$ and $\Delta E=E_{\mathrm{FS}}-E_{\mathrm{IS}}$, where $E_{\mathrm{IS}}, E_{\mathrm{TS}}$ and $E_{\mathrm{FS}}$ represent the energies of initial state (IS), TS, and final state (FS).

we applied the energetic span model analysis for the traditional measure of the efficiency of a catalyst. In catalytic cycle, only one transition state and one intermediate determine the TOF, and they are called the TOFdetermining transition state (TDTS) and the TOF-determining intermediate (TDI), respectively. The energetic span model offers a quantification of the influence of each intermediate and transition state on the TOF for identifying the TDI and TDTS. Once the TDI and TDTS have been identified, a simple estimation of TOF can be determined by the energetic span model approximately:

$$
T O F \approx \frac{k_{B} T}{h} e^{-\delta E / R T}
$$


With

$$
\delta E= \begin{cases}E(\mathrm{TDTS})-E(\mathrm{TDI}) & \text { if TDTS appears after TDI } \\ E(\mathrm{TDTS})-E(\mathrm{TDI})+\Delta G_{\mathrm{r}} & \text { if TDTS appears before TDI }\end{cases}
$$

$\delta E$, the energetic span, corresponds to the apparent activation energy of the full cycle. After knowing the TDTS, the TDI, and when necessary also the reaction energy, this approximation provides all the relevant kinetic information that is required for calculating the TOF of the cycle.

1.2. Surface Models. The optimized lattice constant of $\mathrm{Cu}_{2} \mathrm{O}$ is $4.27 \AA$, which is close to the experimental data. ${ }^{17,18} \mathrm{Cu}_{2} \mathrm{O}(111)$ facet was chosen because it was relatively stable, and a symmetric periodic substrates modeled by the $p(2 \times 2)$ unit cell of four layers copper atoms and eight layers oxygen atoms was built. On the perfect $\mathrm{Cu}_{2} \mathrm{O}(111)$ surface four chemically different types of atoms are named as $\mathrm{Cu}_{\mathrm{CSA}}, \mathrm{Cu}_{\mathrm{CUS}}, \mathrm{O}_{\mathrm{SUB}}$, and $\mathrm{O}_{\mathrm{SUF}}$, respectively. $\mathrm{Cu}_{\mathrm{CSA}}$ is a saturated surface copper atom bound to two adjacent oxygen atoms. And $\mathrm{Cu}_{\mathrm{CUS}}$ is an unsaturated surface copper atom connected to only one adjacent oxygen atom. $\mathrm{O}_{\mathrm{SuB}}$ is a sub-surface oxygen atom, which is saturated and bonds with four $\mathrm{Cu}_{\mathrm{CSA}}$ atoms. While $\mathrm{O}_{\mathrm{SUF}}$ is a surface oxygen atom, which is unsaturated and bonds with three $\mathrm{Cu}_{\mathrm{CSA}}$ atoms. For the $\mathrm{Ru}$-doped $\mathrm{Cu}_{2} \mathrm{O}(111)$, one of the $\mathrm{Cu}_{\mathrm{CSA}}$ atom was replaced by $\mathrm{Ru}$ atom (labeled as $\left.\mathrm{Ru} @ \mathrm{Cu}_{2} \mathrm{O}(111)\right)$. A $18 \AA$ vacuum layer was set between the repeated images in the direction of the surface normal to prevent spurious interactions. The atoms in the top six layers of $\mathrm{Ru} @ \mathrm{Cu}_{2} \mathrm{O}(111)$ were allowed to relax, while the rest of the atoms were fixed at the bulk positions. Carbon atoms in propylene were numbered to facilitate the description of calculated results. As it can be seen in Figure $\mathrm{S} 1$, the end carbon atom, the middle carbon atom and the carbon atom of the methyl in the propylene molecule are named $\mathrm{C}_{1}, \mathrm{C}_{2}$ and $\mathrm{C}_{3}$, respectively.

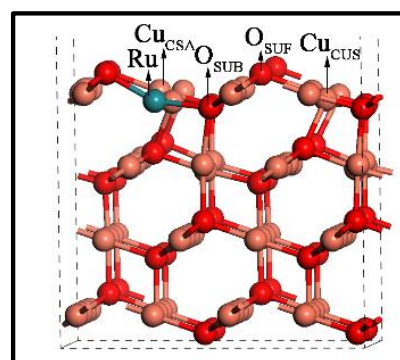

(a)



(b)

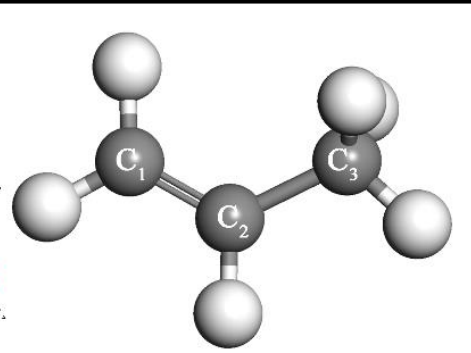

(c)

Figure S1. Side view (a) and top view (b) of $\mathrm{Ru} @ \mathrm{Cu}_{2} \mathrm{O}(111)$ and propylene molecule (c).

\section{Adsorption and dissociation $\mathrm{O}_{2}{ }^{*}$ on the $\mathrm{Ru} @ \mathrm{Cu}_{2} \mathrm{O}(111)$}

For the study of propylene direct epoxidation by molecular $\mathrm{O}_{2}$, it is worth to investigate the activation ability of $\mathrm{O}_{2}$ firstly. Both the side-on type and end-on type adsorption modes of molecular oxygen over different 
adsorption site were taken into account, as shown in Figure $\mathrm{S} 2 .{ }^{20}$ The experimental bond length of $\mathrm{O}_{2}$ molecule is $1.21 \AA{ }^{21}$ and the bond length of optimized $\mathrm{O}_{2}$ in vacuum is $1.24 \AA$, which is in agreement with the previous theoretical work of Illas et al. ${ }^{22}$ According to our previous work, ${ }^{23}$ the bond length of $\mathrm{O}_{2}$ adsorbed on $\mathrm{Cu}_{2} \mathrm{O}(111)$ surface increases to $1.37 \AA$, which indicated that $\mathrm{Cu}_{2} \mathrm{O}(111)$ surface had an activation effect on $\mathrm{O}_{2}$. On the $\mathrm{Ru} @ \mathrm{Cu}_{2} \mathrm{O}(111)$ surface, as shown in Figure 2, the most stable adsorption configuration of molecular oxygen was $\mathrm{O}_{2}(\mathrm{I})$ with the adsorption energy of $-3.35 \mathrm{eV}$ in a side-on two sites adsorption mode ( $\mathrm{Ru}-\mathrm{Cu}$ CUs), and the O-O bond length increases to $1.44 \AA$. The adsorption energy of $\mathrm{O}_{2}(\mathrm{II})$ configuration is $-2.90 \mathrm{eV}$ with two sites adsorption configuration ( $\left.\mathrm{Ru}-\mathrm{Cu}_{\mathrm{CSA}}\right)$, where $\mathrm{O}-\mathrm{O}$ bond length is $1.36 \AA$. For $\mathrm{O}_{2}$ (III) configuration, its adsorption energy is $-2.75 \mathrm{eV}$ in a $\pi$ adsorption type, in which the length of $\mathrm{O}-\mathrm{O}$ bond increases to $1.40 \AA$. The adsorption energy of $\mathrm{O}_{2}(\mathrm{IV})$ is $-2.54 \mathrm{eV}$, in which the molecular oxygen adsorbs on the $\mathrm{Ru}$ by end-on type with a O-O bond length of $1.31 \AA$. The adsorption energy of $\mathrm{O}_{2}(\mathrm{~V})$ is $-1.77 \mathrm{eV}$ with a side-on two sites $\left(\mathrm{Cu}_{\mathrm{CuS}}-\mathrm{Cu}_{\mathrm{CSA}}\right)$, and $\mathrm{O}-\mathrm{O}$ bond length is $1.41 \AA$. And $\mathrm{O}_{2}(\mathrm{VI})$ is not the stable adsorption configuration ( $E_{a d s}=-0.29 \mathrm{eV}$ ) as it binds to $\mathrm{O}_{\text {SUF }}$ site, which is far away from the surface $(>2.50 \AA)$.



Figure S2. Optimized adsorption modes and the related adsorption energy of oxygen atom (a) and molecular oxygen (b) on $\mathrm{Ru} @ \mathrm{Cu}_{2} \mathrm{O}$ (111) and compared to $\mathrm{Cu}_{2} \mathrm{O}$ (111) (c). Purple-red balls represent $\mathrm{O}$ atoms that are not 
belong to the substrate.

For chemisorbed $\mathrm{O}^{*}$, as shown in Figure 2(a), the most stable adsorption configuration of oxygen atom was $\mathrm{O}(\mathrm{I})$, where the $\mathrm{O}$ atom was on the top of the $\mathrm{Ru}$ atom with a bond length of $1.70 \AA$, and the adsorption energy is $-2.88 \mathrm{eV}$. When $\mathrm{O}$ atom are simultaneously connected with $\mathrm{Ru}$ atom and $\mathrm{Cu}$ atom on the $\mathrm{Ru} @ \mathrm{Cu}_{2} \mathrm{O}(111)$ surface (i.e. $\mathrm{O}(\mathrm{II})$ ), the adsorption energy is $-2.80 \mathrm{eV}$. The $\mathrm{O}$ atom is adsorbed on bridge site of $\mathrm{Ru}-\mathrm{Cu}$, where the bond length of $\mathrm{O}-\mathrm{Ru}$ and $\mathrm{O}-\mathrm{Cu}_{\mathrm{Cus}}$ are $1.78 \AA$ and $1.89 \AA$, respectively. When $\mathrm{O}$ atom is bond with three copper atoms on the $\mathrm{Ru} @ \mathrm{Cu}_{2} \mathrm{O}(111)$ surface (i.e. $\mathrm{O}(\mathrm{III})$ ), the adsorption energy is $-1.43 \mathrm{eV}$. The bond length between oxygen atom and $\mathrm{Cu}_{\mathrm{CUS}}$ atom is $1.82 \AA$, while the distance of $\mathrm{O}$ atom and the other two $\mathrm{Cu}_{\mathrm{CSA}}$ atoms is $1.85 \AA$ and $2.12 \AA$, respectively.

The dissociation of oxygen molecule on $\mathrm{Ru} @ \mathrm{Cu}_{2} \mathrm{O}(111)$ in $\mathrm{O}_{2}$ adsorption configuration has a barrier of $0.88 \mathrm{eV}$ (as shown in Figure S3). During the process, the $\mathrm{O}$ atoms moves away from each other. At TS, the distance between two $\mathrm{O}$ atoms is $2.05 \AA$. The dissociation process is exothermic by $0.46 \mathrm{eV}$. Finally, both the two adatom $\mathrm{O}^{*}$ adsorb at the fcc site $\left(\mathrm{Cu}_{\mathrm{CUS}}-\mathrm{Cu}_{\mathrm{CSA}}-\mathrm{Cu}_{\mathrm{CSA}}\right)$. However the oxygen dissociation needs to overcome the energy barrier by $1.07 \mathrm{eV}$ on pure $\mathrm{Cu}_{2} \mathrm{O}(111) \cdot{ }^{23}$ The $\mathrm{Ru}$ atom on $\mathrm{Cu}_{2} \mathrm{O}(111)$ promoted the dissociation of oxygen molecule.

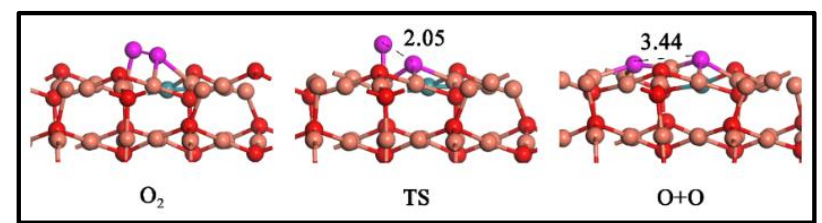

Figure S3. The optimized geometries of IS, TS, and FS in $\mathrm{O}_{2}$ dissociation process on $\mathrm{Ru} @ \mathrm{Cu}_{2} \mathrm{O}(111)$

\section{Reaction Mechanism with the $\mathrm{O}^{*}$ Site Species on $\mathrm{Ru} @ \mathrm{Cu}_{2} \mathrm{O}(111)$.}

3.1. $\mathrm{O}^{*}(\mathrm{I})$ as the oxidant. For the situation of $\mathrm{O}^{*}(\mathrm{I})$, the activation energy of $\mathrm{OMMP}_{1}$ formation is $2.39 \mathrm{eV}$ (as seen in Figure S4), the activation energy required to form $\mathrm{OMMP}_{2}$ is $1.96 \mathrm{eV}$. Although the activation energy of hydrogen formation of allyl group is only $1.28 \mathrm{eV}$, which is significantly lower than epoxidation reaction, the process that hydroxyl takes another $\mathrm{H}$ atom from $\mathrm{C}_{3}$ in $\mathrm{C}_{3} \mathrm{H}_{5} \mathrm{O}$ to form acrolein and $\mathrm{H}_{2} \mathrm{O}$ needs $1.70 \mathrm{eV}$, indicating that both dehydrogenation reaction and epoxidation reaction are difficult to occur. 


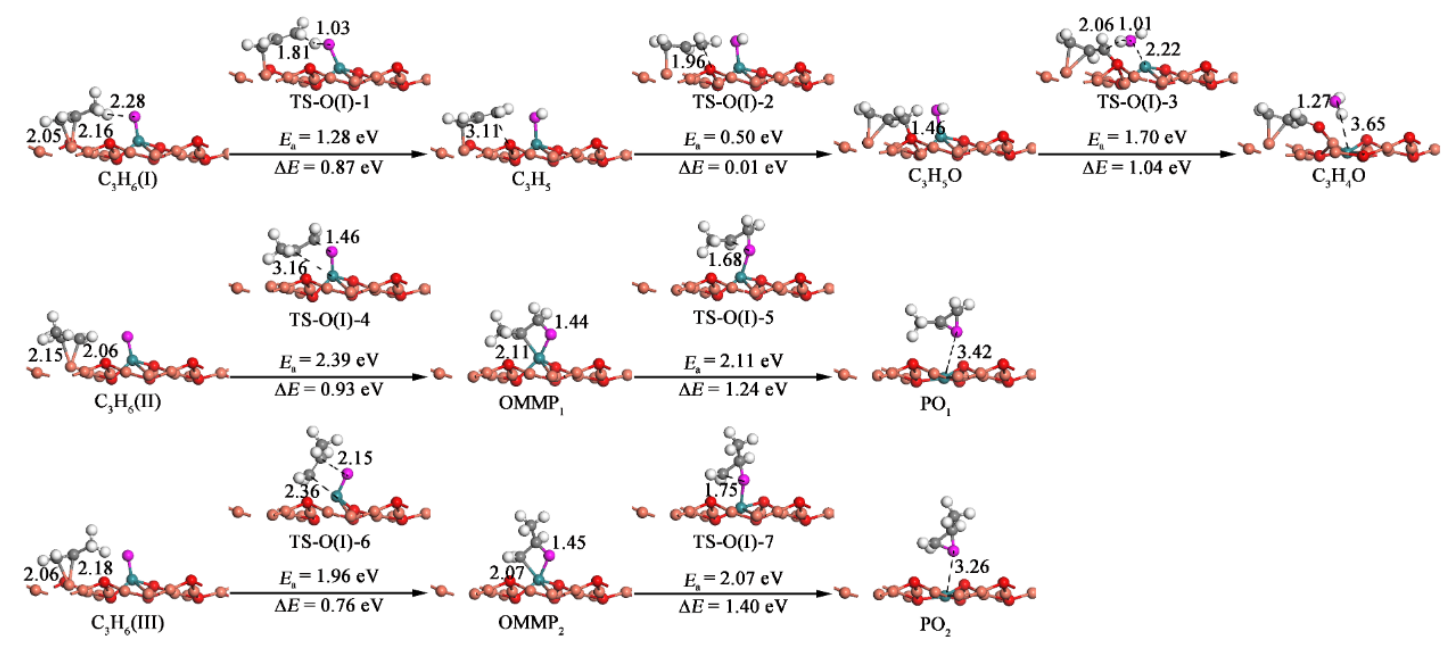

Figure S4. Reaction networks of propylene reacts with O*(I)

3.2. $\mathrm{O}^{*}$ (II) as the oxidant. Since the $\mathrm{O}^{*}(\mathrm{I})$ is easy to move to the bridge site of $\mathrm{Ru}-\mathrm{Cu}_{\mathrm{cus}}$ (i.e. $\mathrm{O}(\mathrm{II})$ ) only with an energy of $0.12 \mathrm{eV}$, the $\mathrm{O}^{*}(\mathrm{II})$ is also studied. As seen from Figure S5, the first step $\left(\mathrm{C}_{3} \mathrm{H}_{6}{ }^{*}+\mathrm{O}_{2}{ }^{*} \rightarrow \mathrm{C}_{3} \mathrm{H}_{5}{ }^{*}+\mathrm{O}^{*}+\mathrm{OH}^{*}\right)$ is found to be endothermic by $0.58 \mathrm{eV}$ as well as the energy barrier of $1.26 \mathrm{eV}$ (TS-O 2 (II)-1: $d_{O-H}=1.12 \AA, d_{C_{3}-H=} 1.60 \AA$ ). The second step $\left(\mathrm{C}_{3} \mathrm{H}_{5}{ }^{*}+\mathrm{O}_{\mathrm{SUF}} \rightarrow \mathrm{C}_{3} \mathrm{H}_{5} \mathrm{O}_{\mathrm{SUF}}{ }^{*}\right)$ is thermoneutral with a barrier of $0.42 \mathrm{eV}$. And the last step $\left(\mathrm{C}_{3} \mathrm{H}_{5} \mathrm{O}_{\text {SuF }}+\mathrm{OH}^{*} \rightarrow \mathrm{C}_{3} \mathrm{H}_{4} \mathrm{O}_{\text {SUF }}+\mathrm{H}_{2} \mathrm{O}^{*}\right)$ has a barrier of $1.64 \mathrm{eV}$. Because of the high barrier of the last step of the AHS processes, it is difficult to carry on dehydrogenation reaction. And the first step to form $\mathrm{OMMP}_{1}\left(\mathrm{OMMP}_{2}\right)$ needs $1.73 \mathrm{eV}(1.74 \mathrm{eV})$, indicating that it also difficult to carry on epoxidation processes. 


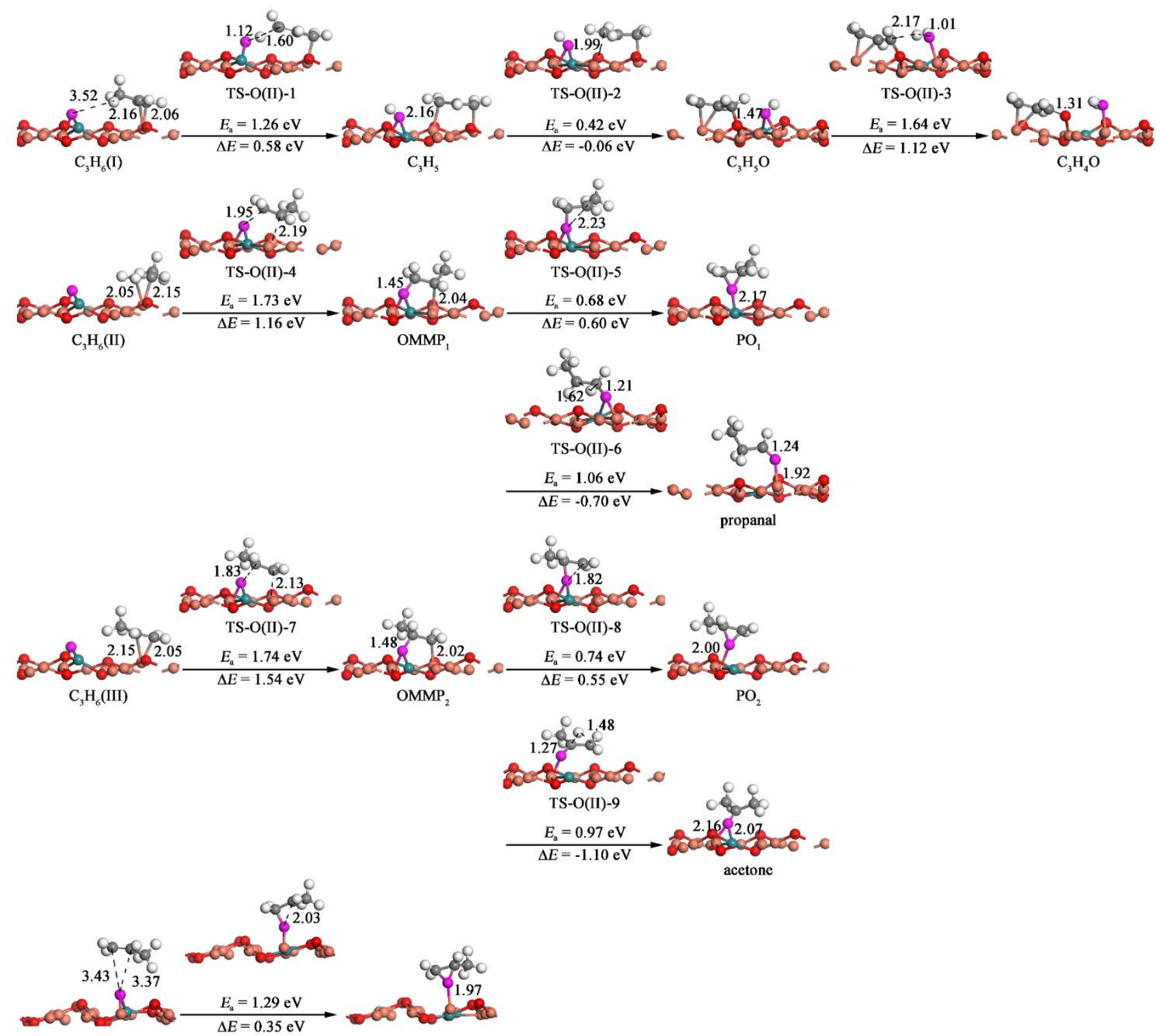

Figure S5. Reaction networks of propylene reacts with $\mathrm{O}^{*}(\mathrm{II})$

\section{Reaction Mechanism with the $\mathrm{O}_{2}{ }^{*}(\mathrm{I})$ Site Species on $\mathrm{Ru} @ \mathrm{Cu}_{2} \mathrm{O}(111)$.}

Due to the asymmetry of the $\mathrm{O}_{2}{ }^{*}(\mathrm{I})$ adsorption configuration, one oxygen atom is combined with $\mathrm{Ru}\left(\mathrm{O}^{*}-\mathrm{Ru}\right)$ and the other oxygen atom is combined with $\mathrm{Cu}_{\mathrm{CUS}}\left(\mathrm{O}^{*}-\mathrm{Cu}_{\mathrm{CUS}}\right)$, so we separately studied the reaction mechanism of its reaction with $\mathrm{C}_{3} \mathrm{H}_{6}$.

\subsection{O*-Ru}

Dehydrogenation Mechanism. As seen from Figure $\mathrm{S} 6$, molecular $\mathrm{C}_{3} \mathrm{H}_{6}$ is adsorbed on the top of $\mathrm{Cu}_{\mathrm{Cus}}$ in a $\pi$ type and it favors the dehydrogenation reaction, with the adsorption energy of $-1.53 \mathrm{eV}$. The first step $\left(\mathrm{C}_{3} \mathrm{H}_{6}{ }^{*}+\mathrm{O}_{2}{ }^{*} \rightarrow \mathrm{C}_{3} \mathrm{H}_{5}{ }^{*}+\mathrm{O}^{*}+\mathrm{OH}^{*}\right)$ is found to be endothermic by $1.50 \mathrm{eV}$ as well as the energy barrier of $1.93 \mathrm{eV}$ (TS-O $\left.\mathrm{O}_{2}(\mathrm{I})-1: \mathrm{d}_{\mathrm{O}-\mathrm{H}}=1.22 \AA, \mathrm{d}_{\mathrm{C}_{3}-\mathrm{H}}=1.56 \AA\right)$. The formed Allyl group is adsorbed on the surface in the $\eta^{1}\left(\mathrm{C}_{1}\right)$ - 
$\eta^{1}\left(\mathrm{C}_{3}\right)$ mode $\left(\mathrm{d}_{\mathrm{C}_{1}-\mathrm{Cu}_{\mathrm{CUS}}}=1.99 \AA, \mathrm{d}_{\mathrm{C}_{3}-\mathrm{Cu}_{\mathrm{CSA}}}=2.05 \AA\right)$. Because of the high barrier of the first step of the AHS processes, it is difficult to carry on dehydrogenation reaction.

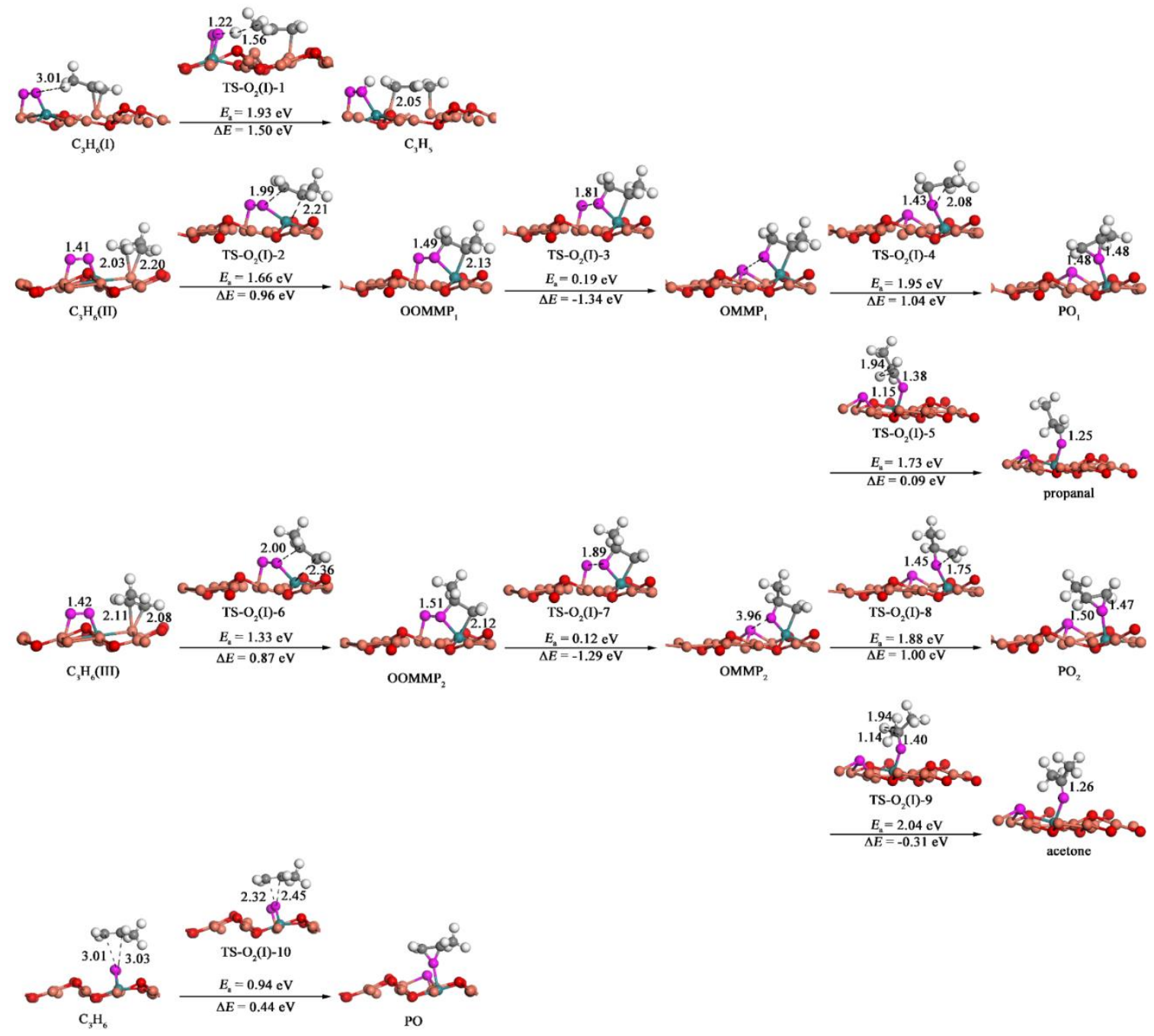

Figure S6. Reaction networks and energetic profiles of propylene epoxidation with the oxygen atom on $\mathrm{Ru}$ of $\mathrm{O}_{2}{ }^{*}(\mathrm{I})$ species on $\mathrm{Ru} @ \mathrm{Cu}_{2} \mathrm{O}(111)$. Bond lengths are in $\AA$.

Epoxidation processes via OOMMP intermediate. $\mathrm{C}_{3} \mathrm{H}_{6}$ is first adsorbed in a $\mathrm{C}_{3} \mathrm{H}_{6}(\mathrm{I})$ configuration with the adsorption energy of $-1.53 \mathrm{eV}$, and then migrated on the surface of $\mathrm{Ru} @ \mathrm{Cu}_{2} \mathrm{O}$ to form either $\mathrm{C}_{3} \mathrm{H}_{6}(\mathrm{II})$ or $\mathrm{C}_{3} \mathrm{H}_{6}(\mathrm{III})$ configurations.

For $\mathrm{C}_{3} \mathrm{H}_{6}(\mathrm{II})$ type, $\mathrm{C}_{3} \mathrm{H}_{6}$ binds to $\mathrm{Cu}_{\mathrm{CUS}}$ near the $\mathrm{Ru}$ atom in a $\pi$ mode $\left(\mathrm{d}_{\mathrm{C}_{1}-\mathrm{Cu}_{\mathrm{CUS}}}=2.03 \AA, \mathrm{d}_{\mathrm{C}_{2}-\mathrm{Cu}_{\mathrm{CUS}}}=2.20\right.$ $\AA$ ), and its adsorption energy is $-1.17 \mathrm{eV}$. Under the attraction of $\mathrm{O}_{2}{ }^{*}$, the $\mathrm{C}_{1}-\mathrm{Cu}_{\mathrm{CUS}}$ bond is gradually to broken, $\mathrm{C}_{1}$ reacts with the $\mathrm{O}$ atom adjacent to the $\mathrm{Ru}$ atom to form a $\mathrm{C}_{1}-\mathrm{O}$ bond $\left(\mathrm{d}_{\mathrm{C}_{1}-\mathrm{O}}=1.49 \AA\right), \mathrm{C}_{2}$ is bonded to $\mathrm{Ru}$ 
with the bond length of $2.13 \AA$, and thus forming OOMMP ${ }_{1}$ species. This step is endothermic by $0.96 \mathrm{eV}$ and had a barrier of $1.66 \mathrm{eV}\left(\mathrm{TS}_{-} \mathrm{O}_{2}(\mathrm{I})-2: \mathrm{d}_{\mathrm{C}_{1}-\mathrm{O}}=1.99 \AA, \mathrm{d}_{\mathrm{C}_{2}-\mathrm{Ru}}=2.21 \AA\right)$. The formed OOMMP ${ }_{1}$ species than forms $\mathrm{OMMP}_{1}$ via $\mathrm{O}-\mathrm{O}$ bond broken $\left(\mathrm{OOMMP}_{1} \rightarrow \mathrm{OMMP}_{1}+\mathrm{O}\right)$. This step is exothermic by $1.34 \mathrm{eV}$, and the activation energy is $0.19 \mathrm{eV}\left(\mathrm{TS}_{2} \mathrm{O}_{2}(\mathrm{I})-3: \mathrm{d}_{\mathrm{O}-\mathrm{O}}=1.81 \AA\right.$ ), which means the facile formation of OMMP $\mathrm{OM}_{1}$ intermediate. After the formation of $\mathrm{OMMP}_{1}$, its can either to form $\mathrm{PO}_{1}$ or propanal in the following reaction processes. For the formation of $\mathrm{PO}_{1}$ via $\mathrm{OMMP}_{1}$, its barrier is $1.95 \mathrm{eV}\left(\mathrm{TS}-\mathrm{O}_{2}(\mathrm{I})-4: \mathrm{d}_{\mathrm{C}_{2}-\mathrm{O}}=2.08 \AA\right)$ and it is endothermic by $1.04 \mathrm{eV}$. On the other hand, the energy barrier for the formation of propanal is $1.73 \mathrm{eV}$ via TS$\mathrm{O}_{2}(\mathrm{I})-5\left(\mathrm{~d}_{\mathrm{C}_{1}-\mathrm{H}}=1.15 \AA, \mathrm{d}_{\mathrm{C}_{2}-\mathrm{H}}=1.94 \AA, \mathrm{d}_{\mathrm{C}_{1}-\mathrm{O}}=1.38 \AA\right)$, and it is exothermic by $0.09 \mathrm{eV}$. The production of propanal is easier than that of $\mathrm{PO}_{1}$ via the $\mathrm{OMMP}_{1}$.

For $\mathrm{C}_{3} \mathrm{H}_{6}(\mathrm{III})$ type, $\mathrm{C}_{3} \mathrm{H}_{6}$ binds to $\mathrm{Cu}_{\mathrm{CUS}}$ in a $\pi$ type with the adsorption energy of $-1.25 \mathrm{eV}$. The OOMMP 2 formation is found to be an endothermic process $(0.87 \mathrm{eV})$ with a barrier of $1.33 \mathrm{eV}$ via TS-O $\mathrm{O}_{2}(\mathrm{I})-6\left(\mathrm{~d}_{\mathrm{C}_{2}-\mathrm{O}}=\right.$ $2.00 \AA$ ). Next the $\mathrm{O}-\mathrm{O}$ bond would be broken and form $\mathrm{OMMP}_{2}$, and it was found it is a highly exothermic process and with a low barrier $(0.12 \mathrm{eV})$. When $\mathrm{OMMP}_{2}$ was formed, its further reaction to form $\mathrm{PO}_{2}$ with a barrier of $1.88 \mathrm{eV}$, whereas to form acetone with a barrier of $2.04 \mathrm{eV}$, higher than that of $\mathrm{PO}_{2}$ formation.

Both AHS process and epoxidation process can be found that the energy barrier is very high in general $(>1.7$ $\mathrm{eV}$ ), so the oxygen atom on $\mathrm{Ru}$ of $\mathrm{O}_{2}{ }^{*}(\mathrm{I})$ might not be a candidate for PO formation. Then we focus on the reaction between $\mathrm{C}_{3} \mathrm{H}_{6}$ and the oxygen atom on $\mathrm{Cu}_{\text {of }} \mathrm{O}_{2}{ }^{*}(\mathrm{I})$.

\section{2 $\mathrm{O}^{*}-\mathrm{Cu}$ CUS}

Dehydrogenation Mechanism. As seen from Figure $\mathrm{S} 7$, molecular $\mathrm{C}_{3} \mathrm{H}_{6}$ is adsorbed on the top of $\mathrm{Cu}_{\text {Cus }}$ in a $\pi$ type and with the adsorption energy of $-1.55 \mathrm{eV}$. The first step $\left(\mathrm{C}_{3} \mathrm{H}_{6}{ }^{*}+\mathrm{O}_{2}{ }^{*} \rightarrow \mathrm{C}_{3} \mathrm{H}_{5}{ }^{*}+\mathrm{O}^{*}+\mathrm{OH}^{*}\right)$ is found to be endothermic by $0.06 \mathrm{eV}$ as well as the energy barrier of $0.43 \mathrm{eV}$ viaTS-O $\mathrm{O}_{2}(\mathrm{I})-1\left(\mathrm{~d}_{\mathrm{O}-\mathrm{H}}=1.26 \AA \mathrm{d}_{\mathrm{C}_{3}-\mathrm{H}}=1.34\right.$ $\left.\AA, \mathrm{d}_{\mathrm{O}-\mathrm{O}}=2.94 \AA\right)$. The formed Allyl group is adsorbed on the surface in the $\eta^{1}\left(\mathrm{C}_{1}\right)-\eta^{1}\left(\mathrm{C}_{3}\right) \operatorname{mode}\left(\mathrm{d}_{\mathrm{C}_{1}-\mathrm{Cu}_{\mathrm{CUS}}}=\right.$ $1.97 \AA, \mathrm{d}_{\mathrm{C}_{3}-\mathrm{Cu}_{\mathrm{CSA}}}=2.13 \AA$ ). Then allyl approaches to $\mathrm{O}_{\mathrm{SUF}}$ to form $\mathrm{C}_{3} \mathrm{H}_{5} \mathrm{O}$ with a barrier of $1.11 \mathrm{eV}\left(\mathrm{TS}-\mathrm{O}_{2}(\mathrm{I})-\right.$ 2: $\left.\mathrm{d}_{\mathrm{C}_{3}-\mathrm{O}_{\mathrm{SUF}}}=2.01 \AA\right)$. The third step $\left(\mathrm{C}_{3} \mathrm{H}_{5} \mathrm{O}^{*}+\mathrm{OH}^{*} \rightarrow \mathrm{C}_{3} \mathrm{H}_{4} \mathrm{O}^{*}+\mathrm{H}_{2} \mathrm{O}^{*}\right)$ is exothermic by $0.37 \mathrm{eV}$ with a barrier of $1.08 \mathrm{eV}$ via TS-O $\mathrm{O}_{2}(\mathrm{I})-3\left(\mathrm{~d}_{\mathrm{O}-\mathrm{H}}=1.16 \AA, \mathrm{d}_{\mathrm{C}_{3}-\mathrm{H}}=1.55 \AA\right)$. The relatively low barrier of the AHS processes means that it is easy to carry on dehydrogenation reaction. 
Epoxidation processes via OOMMP intermediate. For $\mathrm{C}_{3} \mathrm{H}_{6}(\mathrm{II})$ type, $\mathrm{C}_{3} \mathrm{H}_{6}$ binds to $\mathrm{Cu}_{\mathrm{Cus}}$ near the $\mathrm{Ru}$ atom in a $\pi$ mode $\left(\mathrm{d}_{\mathrm{C}_{1}-\mathrm{Cu}_{\mathrm{CUS}}}=2.06 \AA, \mathrm{d}_{\mathrm{C}_{2}-\mathrm{Cu}_{\mathrm{CUS}}}=2.16 \AA\right)$, and its adsorption energy is $-1.51 \mathrm{eV}$. Under the attraction of $\mathrm{O}_{2}{ }^{*}$, the $\mathrm{C}_{1}-\mathrm{Cu}_{\text {cus }}$ bond is gradually to broken, $\mathrm{C}_{1}$ reacts with the $\mathrm{O}$ atom adjacent to the $\mathrm{Cu}$ atom to form a $\mathrm{C}_{1}-\mathrm{O}$ bond, $\mathrm{O}-\mathrm{O}$ bond breaks in this process, and thus forming $\mathrm{OMMP}_{1}$ species. This step is exothermic by 0.36 $\mathrm{eV}$ and had a barrier of $1.56 \mathrm{eV}\left(\mathrm{TS}-\mathrm{O}_{2}(\mathrm{I})-4: \mathrm{d}_{\mathrm{C}_{1}-\mathrm{O}}=2.13 \AA, \mathrm{d}_{\mathrm{C}_{2}-\mathrm{Ru}}=2.24 \AA, \mathrm{d}_{\mathrm{O}-\mathrm{O}}=3.38 \AA\right)$. The OMMP can either to form $\mathrm{PO}_{1}$ or propanal in the following reaction processes. For the formation of $\mathrm{PO}_{1}$ via $\mathrm{OMMP}_{1}$, its barrier is $0.54 \mathrm{eV}\left(\mathrm{TS}-\mathrm{O}_{2}(\mathrm{I})-5: \mathrm{d}_{\mathrm{C}_{2}-\mathrm{O}}=2.16 \AA\right)$ and it is endothermic by $0.58 \mathrm{eV}$. On the other hand, the energy barrier for the formation of propanal is $0.40 \mathrm{eV}$ via TS-O $\mathrm{O}_{2}(\mathrm{I})-6\left(\mathrm{~d}_{\mathrm{C}_{1}-\mathrm{H}}=1.19 \AA, \mathrm{d}_{\mathrm{C}_{2}-\mathrm{H}}=1.79 \AA\right)$, and it is exothermic by $1.45 \mathrm{eV}$. The production of propanal is easier than that of $\mathrm{PO}_{1}$ via the $\mathrm{OMMP}_{1}$.

For $\mathrm{C}_{3} \mathrm{H}_{6}(\mathrm{III})$ type, $\mathrm{C}_{3} \mathrm{H}_{6}$ binds to $\mathrm{Cu}_{\mathrm{CUS}}$ in a $\pi$ type with the adsorption energy of $-1.55 \mathrm{eV}$. The $\mathrm{OMMP}_{2}$ formation is found to be an endothermic process $(0.28 \mathrm{eV})$ with a barrier of $1.42 \mathrm{eV}$ via TS-O $\mathrm{O}_{2}(\mathrm{I})-7\left(\mathrm{~d}_{\mathrm{C}_{2}-\mathrm{O}}=\right.$ $2.38 \AA, \mathrm{d}_{\mathrm{C}_{1}-\mathrm{Cu}_{\mathrm{CSA}}}=2.13 \AA$ ). Then $\mathrm{OMMP}_{2}$ can process the further reaction to form $\mathrm{PO}_{2}$ with a barrier of 0.51 $\mathrm{eV}$, whereas to form acetone with a barrier of $0.44 \mathrm{eV}$, a little lower than that of $\mathrm{PO}_{2}$ formation. Compared to epoxidation process, the oxygen atom on $\mathrm{Cu}$ of $\mathrm{O}_{2}{ }^{*}(\mathrm{I})$ is favorable to dehydrogenate due the relatively lower energy barrier (1.11 vs $1.42 \mathrm{eV})$, so $\mathrm{O}_{2}{ }^{*}(\mathrm{I})$ might not be a candidate for $\mathrm{PO}$ formation. 

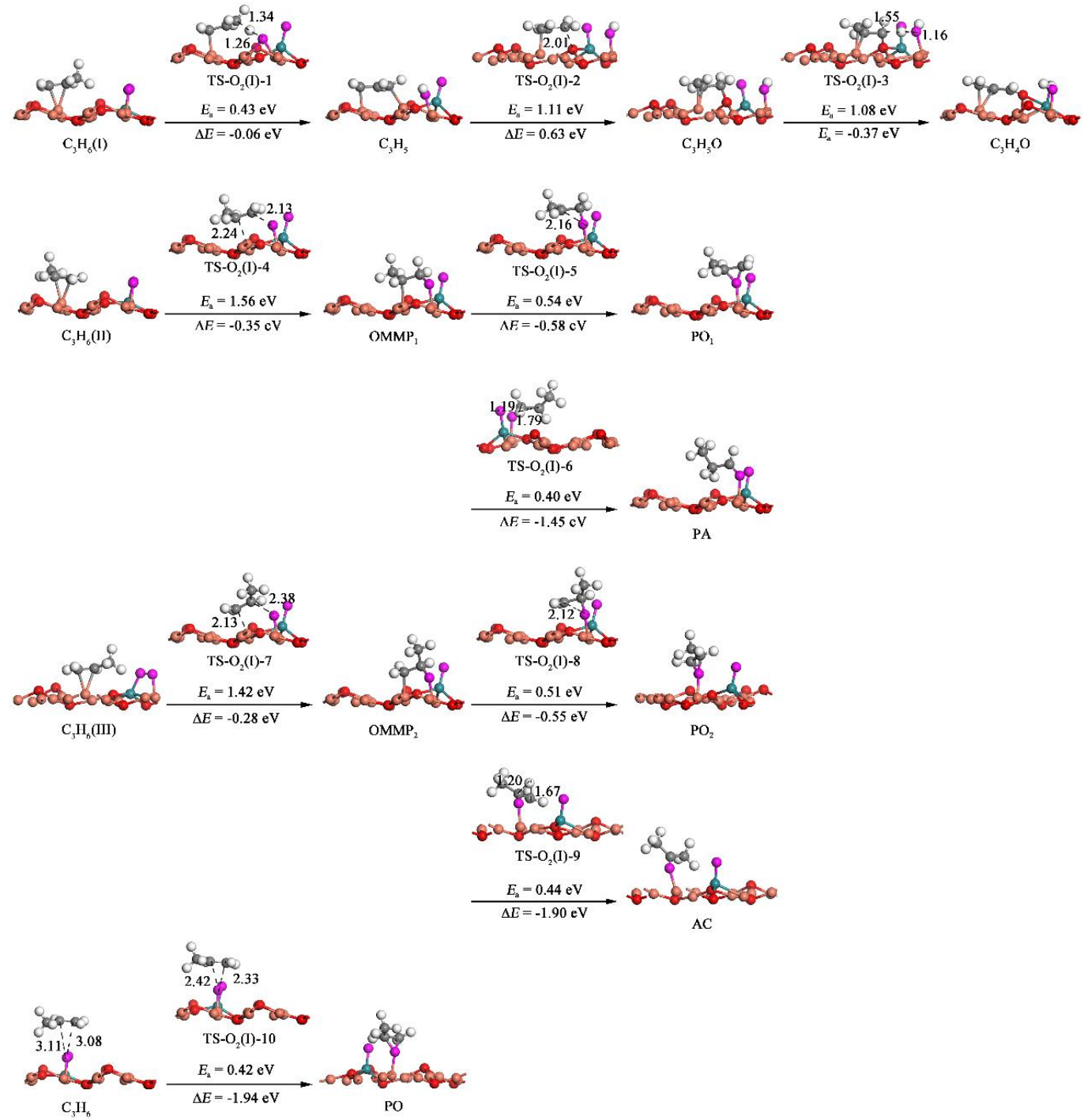

Figure S7. Reaction networks and energetic profiles of propylene epoxidation with the oxygen atom on $\mathrm{Cu}$ of $\mathrm{O}_{2}^{*}(\mathrm{I})$ species on $\mathrm{Ru} @ \mathrm{Cu}_{2} \mathrm{O}(111)$. Bond lengths are in $\AA$.

\section{Reaction Kinetics of Propyene on $\mathrm{Ru} @ \mathrm{Cu}_{2} \mathrm{O}$ (111) by Lattice Oxygen $\left(\mathrm{O}_{\mathrm{SUF}}\right)$ Active Species}

Dehydrogenation Mechanism (AHS). During the AHS process, firstly molecular propylene is adsorbed on $\mathrm{Ru} @ \mathrm{Cu}_{2} \mathrm{O}(111)$ in a $\pi$ adsorption type with $\mathrm{Cu}_{\mathrm{CUS}}\left(\mathrm{d}_{\mathrm{C}_{1}-\mathrm{Cu}_{\mathrm{CUS}}}=2.06 \AA, \mathrm{d}_{\mathrm{C}_{2}-\mathrm{Cu}_{\mathrm{CUS}}}=2.12 \AA\right.$, and $\mathrm{d}_{\mathrm{C}_{3}-\mathrm{H}}=2.50$ $\AA$ ), as seen in Figure $\mathrm{S} 8$. Then the $\mathrm{O}_{\text {SUF }}$ on the surface of $\mathrm{Ru} @ \mathrm{Cu}_{2} \mathrm{O}$ (111) captures hydrogen on $\mathrm{C}_{3}$ to form allyl $\left(\mathrm{C}_{3} \mathrm{H}_{5}\right)$ and hydroxyl groups. This step is endothermic by $1.70 \mathrm{eV}$, and the related energy barrier is $1.75 \mathrm{eV}$ through TS-O $\mathrm{SSFF}_{-1}\left(\mathrm{~d}_{\mathrm{C}_{3}-\mathrm{H}}=1.84 \AA, \mathrm{d}_{\mathrm{O}_{\mathrm{SUF}}-\mathrm{H}}=1.03 \AA\right)$. Then the allyl group is slightly rotated, and $\mathrm{C}_{3}$ is bond to another $\mathrm{O}_{\mathrm{SUF}}$ on the surface to form $\mathrm{C}_{3} \mathrm{H}_{5} \mathrm{O}$. This step is exothermic by $0.06 \mathrm{eV}$, and the related energy barrier is $0.52 \mathrm{eV}$ via TS-O $\mathrm{SUF}_{\mathrm{SUF}}-2\left(\mathrm{~d}_{\mathrm{C}_{3}-\mathrm{O}_{\mathrm{SUF}}}=1.94 \AA\right)$. Next, the unsaturated $\mathrm{Ru}$ atom captured the hydrogen on $\mathrm{C}_{3}$ in 
$\mathrm{C}_{3} \mathrm{H}_{5} \mathrm{O}$ to form acrolein and ruthenium hydride. The reaction is exothermic by $0.13 \mathrm{eV}$ and the activation energy of acrolein formation is $1.37 \mathrm{eV}$ via TS-O $\mathrm{SuF}_{-3}\left(\mathrm{~d}_{\mathrm{C}_{3}-\mathrm{H}}=1.57 \AA\right)$. Then $\mathrm{H}$ species bound to $\mathrm{Ru}$ reacts with $\mathrm{OH}$ to form $\mathrm{H}_{2} \mathrm{O}$ through TS-OSUF- $4\left(\mathrm{~d}_{\mathrm{Ru}-\mathrm{H}}=1.66 \AA, \mathrm{d}_{\mathrm{O}-\mathrm{H}}=1.36 \AA\right)$, and it is endothermic by $0.37 \mathrm{eV}$ with the barrier of $1.00 \mathrm{eV}$. Throughout the whole AHS process, the first dehydrogenation step is the controlling step with the activation energy of $1.75 \mathrm{eV}$.

Epoxidation Mechanism via the OMMP Intermediate. Two different adsorption modes for propylene contribute to the epoxidation of propylene, as shown in Figure $\mathrm{S} 3$, where $\mathrm{C}_{3} \mathrm{H}_{6}(\mathrm{II})$ is favorable for the formation of $\mathrm{OMMP}_{1}$ intermediate and $\mathrm{C}_{3} \mathrm{H}_{6}(\mathrm{III})$ is favorable for the formation of $\mathrm{OMMP}_{2}$ intermediate.

For the $\mathrm{C}_{3} \mathrm{H}_{6}$ (II) adsorption configuration, the molecular propylene is adsorbed on $\mathrm{Cu}_{\mathrm{CUS}}$ in a $\pi$ adsorption type, and its adsorption energy is $-1.52 \mathrm{eV}$ with the $\mathrm{C}_{1}-\mathrm{Cu}_{\mathrm{CUS}}$ bond length of $2.05 \AA$ and $\mathrm{C}_{2}-\mathrm{Cu}_{\mathrm{Cus}}$ bond length of $2.13 \AA$, where $\mathrm{C}_{1}$ is closer to $\mathrm{O}_{\mathrm{SuF}}$ than $\mathrm{C}_{2}$. During the epoxidation process, $\mathrm{C}_{1}-\mathrm{Cu}_{\mathrm{Cus}}$ bond tends to break, and $\mathrm{C}_{1}$ binds to the $\mathrm{O}_{\mathrm{SUF}}$ with a bond length of $1.50 \AA, \mathrm{C}_{2}$ binds to $\mathrm{Cu}_{\mathrm{CUS}}$ with a bond length of $1.96 \AA$, and thus $\mathrm{OMMP}_{1}$ was formed. The $\mathrm{OMMP}_{1}$ formation process is exothermic by $1.40 \mathrm{eV}$, and the associated energy barrier is $1.55 \mathrm{eV}$ through TS-O $\mathrm{SUF}_{-} 5\left(\mathrm{~d}_{\mathrm{C}_{1}-\mathrm{O}}=1.83 \AA, \mathrm{d}_{\mathrm{C}_{2}-\mathrm{Cu}}=2.00 \AA\right)$. OMMP 1 can either to form PO or propanal for further reaction processes. In the formation of PO route, the $\mathrm{C}_{2}-\mathrm{Cu}_{\mathrm{Cus}}$ bond broken firstly and followed by the $\mathrm{C}_{2}-\mathrm{O}_{\text {SuF }}$ bond formation to form $\mathrm{PO}_{1}$ in which the $\mathrm{C}_{1}-\mathrm{O}_{\text {SuF }}$ bond length is $1.45 \AA$ and $\mathrm{C}_{2}-\mathrm{O}_{\text {SuF }}$ bond length is 1.47 $\AA$. The formation of $\mathrm{PO}_{1}$ process is endothermic by $0.74 \mathrm{eV}$, and the corresponding activation barrier is $1.52 \mathrm{eV}$ via TS-O $\mathrm{SUF}_{-}-6\left(\mathrm{~d}_{\mathrm{C}_{2}-\mathrm{O}_{\mathrm{SUF}}}=1.96 \AA\right)$. For the formation of propanal via OMMP ${ }_{1}$ intermediate, it processed the breaking of $\mathrm{C}_{2}-\mathrm{Cu}_{\mathrm{CUS}}$ bond, followed by the $\mathrm{H}$ transfer from $\mathrm{C}_{1}$ to $\mathrm{C}_{2}\left(\mathrm{~d}_{\mathrm{C}_{1}-\mathrm{O}_{\mathrm{SuF}}}=1.24 \AA\right)$, and thus the propanal was formed. This process is exothermic by $0.26 \mathrm{eV}$ and had a barrier of $2.17 \mathrm{eV}$ via TS-O $\mathrm{SUF}_{-}-7\left(\mathrm{~d}_{\mathrm{C}_{1}-\mathrm{H}}=1.19 \AA\right.$, $\mathrm{d}_{\mathrm{C}_{2}-\mathrm{H}}=1.73 \AA, \mathrm{d}_{\mathrm{C}_{1}-\mathrm{O}_{\mathrm{SUF}}}=1.35 \AA$ ). For the $\mathrm{OMMP}_{1}$ species mechanism, PO $\mathrm{P}_{1}$ formation is more favorable than that of propanal.

For the $\mathrm{C}_{3} \mathrm{H}_{6}$ (III) adsorption configuration, in which proylene is adsorbed on top of $\mathrm{Cu}_{\mathrm{CUS}}$ in a $\pi$ type $\left(\mathrm{d}_{\mathrm{C}_{1}-\mathrm{Cu}_{\mathrm{CUS}}}=2.05 \AA, \mathrm{d}_{\mathrm{C}_{2}-\mathrm{Cu}_{\mathrm{CUS}}}=2.15 \AA\right)$, and the adsorption energy is $-1.47 \mathrm{eV}$. During the $\mathrm{OMMP}_{2}$ formation process, it including the $\mathrm{C}_{2}-\mathrm{Cu}_{\mathrm{CUS}}$ bond broken and $\mathrm{C}_{2}-\mathrm{O}_{\text {SUF }}$ bond formation. This step is endothermic by 1.01 $\mathrm{eV}$, and the related energy barrier is $1.03 \mathrm{eV}$ via TS-O $\mathrm{OSUF}_{\mathrm{S}}-8\left(\mathrm{~d}_{\mathrm{C}_{1}-\mathrm{Cu}_{\mathrm{CUS}}}=1.97 \AA, \mathrm{d}_{\mathrm{C}_{2}-\mathrm{O}_{\mathrm{SUF}}}=1.79 \AA\right)$. Obviously, 
it is easier to form an $\mathrm{OMMP}_{2}$ intermediate than to form an $\mathrm{OMMP}_{1}$ intermediate. The formed $\mathrm{OMMP}_{2}$ continues to be oxidized to form $\mathrm{PO}_{2}$ or acetone. In the formation of $\mathrm{PO}_{2}$, it involves the $\mathrm{C}_{1}-\mathrm{Cu}_{\mathrm{Cus}}$ bond broken and $\mathrm{C}_{1}$ Osurbond formation. This step is endothermic by $0.90 \mathrm{eV}$, and the activation energy is $1.91 \mathrm{eV}$ viaTS-OSUF- -9 $\left(\mathrm{d}_{\mathrm{C}_{2}-\mathrm{O}_{\mathrm{SUF}}}=1.48 \AA, \mathrm{d}_{\mathrm{C}_{1}-\mathrm{O}_{\mathrm{SUF}}}=2.04 \AA\right)$. For the acetone formation, $\mathrm{C}_{1}-\mathrm{Cucus}$ bond in $\mathrm{OMMP}_{2}$ was broken, and the $\mathrm{H}$ atom transfers from $\mathrm{C}_{2}$ to $\mathrm{C}_{1}$ to form acetone. This step is exothermic by $0.29 \mathrm{eV}$, and the energy barrier is $2.52 \mathrm{eV}$ via TS-O $\mathrm{SUF}_{\mathrm{SU}}-10\left(\mathrm{~d}_{\mathrm{C}_{2}-\mathrm{H}}=1.19 \AA, \mathrm{d}_{\mathrm{C}_{1}-\mathrm{H}}=1.71 \AA, \mathrm{d}_{\mathrm{C}_{2}-\mathrm{O}_{\mathrm{SUF}}}=1.36 \AA\right)$, much higher than that of $\mathrm{PO}_{2}$ formation. Obviously, $\mathrm{PO}_{2}\left(\mathrm{PO}_{1}\right)$ is easier to be produced in OMMP mechanism compared to acetone (propanal). Moreover, it was found that the $\mathrm{OMMP}_{2}$ intermediate is easier to be produced than $\mathrm{OMMP}_{1}$ intermediate due to its relatively low barrier ( $1.03 \mathrm{vs} 1.55 \mathrm{eV})$, but the $\mathrm{PO}_{2}$ formation barrier is much higher than that of $\mathrm{PO}_{1}$ (1.91 vs. $1.52 \mathrm{eV}$ ), so $\mathrm{OMMP}_{1}$ mechanism is the major route to form PO. Compared to AHS process, it can be found that the $\mathrm{OMMP}_{1}$ has low barrier $(1.52 \mathrm{vs} .1 .75 \mathrm{eV})$, so PO formation selectivity might be higher than that of acrolein, but the catalytic activity would be low due to the high barrier $(>1.5 \mathrm{eV})$.

Direct E-R Reaction Mechanism. For the $\mathrm{C}_{3} \mathrm{H}_{6}(\mathrm{~g})+\mathrm{O}_{\mathrm{SUF}} \rightarrow \mathrm{PO}^{*}$, it was endothermic by $1.02 \mathrm{eV}$ and with a high barrier $(1.43 \mathrm{eV})$. Moreover, the above E-R reaction mechanism processes with the Gibbs free energy change is much positive at $498 \mathrm{~K}\left(\triangle \mathrm{G}_{\mathrm{r}}=2.00 \mathrm{eV}\right)$, meaning unfavorable in thermochemical aspect. For the kinetic behave, if the same IS as the L-H type mechanism was chosen, the barrier would be higher (i.e. $1.04+1.43=2.47$ $\mathrm{eV})$. So the direct E-R reaction mechanism had no probability to occur.

These calculations results indicated that lattice oxygen is not the active oxygen specie on $\mathrm{Ru} @ \mathrm{Cu}_{2} \mathrm{O}(111)$ for the propylene epoxidation because of its high barrier either by the OMMP intermediate mechanism or by the E-R type mechanism. The reason might be lattice oxygen binds to $\mathrm{Cu}$ ions too strong to reacts with the molecular propylene. So the molecular $\mathrm{O}_{2}$ should be added to the reactants and as the oxidant for the occurring of epoxidation reactions. 



Figure S8. Reaction networks of propylene reacts with $\mathrm{O}_{\text {SUF }}$ 
Table S1. Energetic results of propylene reaction on $\mathrm{Ru} @ \mathrm{Cu}_{2} \mathrm{O}(111)$ (unit: eV)

\begin{tabular}{|c|c|c|c|c|c|c|}
\hline \multirow{2}{*}{ Reaction } & \multicolumn{2}{|c|}{$\mathbf{O}_{\text {SUF }}$} & \multicolumn{2}{|c|}{$\mathbf{O}^{*}$} & \multicolumn{2}{|c|}{$\mathbf{O}_{2}{ }^{*}$} \\
\hline & $\Delta E / \mathrm{eV}$ & $E_{\mathrm{a}} / \mathrm{eV}$ & $\Delta E / \mathrm{eV}$ & $E_{\mathrm{a}} / \mathrm{eV}$ & $\Delta E / \mathrm{eV}$ & $E_{\mathrm{a}} / \mathrm{eV}$ \\
\hline $\mathrm{M} 1 \mathrm{C}_{3} \mathrm{H}_{6}(\mathrm{I})^{*}+\mathrm{O}^{*}\left(\mathrm{O}_{2} *\right) \rightarrow \mathrm{C}_{3} \mathrm{H}_{5} *+\mathrm{OH}^{*}\left(\mathrm{OOH}^{*}\right)$ & 1.70 & 1.75 & -1.27 & 0.99 & -0.17 & 0.88 \\
\hline $\mathrm{M} 2 \mathrm{C}_{3} \mathrm{H}_{5} *+\mathrm{O}_{\text {SUF }} * \rightarrow \mathrm{C}_{3} \mathrm{H}_{5} \mathrm{O}_{\text {SUF }} *$ & -0.06 & 0.52 & 0.31 & 0.71 & 0.33 & 0.63 \\
\hline $\mathrm{M} 3 \mathrm{OOH}^{*} \rightarrow \mathrm{O}^{*}+\mathrm{OH}^{*}$ & - & - & - & - & -2.92 & 0.51 \\
\hline $\mathrm{M} 4 \mathrm{C}_{3} \mathrm{H}_{5} \mathrm{O}_{\text {SuF }} *+\mathrm{OH}^{*} \rightarrow \mathrm{C}_{3} \mathrm{H}_{4} \mathrm{O}_{\text {SUF }} *+\mathrm{H}_{2} \mathrm{O}^{*}$ & - & - & 0.26 & 1.28 & 0.42 & 1.20 \\
\hline M5 $\mathrm{C}_{3} \mathrm{H}_{5} \mathrm{O}_{\text {SuF }} *+\mathrm{Ru}^{*} \rightarrow \mathrm{C}_{3} \mathrm{H}_{4} \mathrm{O}_{\text {SUF }} *+\mathrm{RuH}^{*}$ & -0.13 & 1.37 & - & - & - & - \\
\hline $\mathrm{M} 6 \mathrm{RuH}^{*}+\mathrm{OH}^{*} \rightarrow \mathrm{Ru}^{*}+\mathrm{H}_{2} \mathrm{O} *$ & 0.37 & 1.00 & - & - & - & - \\
\hline M7 $\mathrm{C}_{3} \mathrm{H}_{6}(\mathrm{II})^{*}+\mathrm{O}^{*}\left(\mathrm{O}_{2} *\right) \rightarrow \mathrm{OMMP}_{1} *\left(\mathrm{OOMMP}_{1} *\right)$ & 1.40 & 1.55 & 0.49 & 1.47 & 0.72 & 1.46 \\
\hline $\mathrm{M} 8 \mathrm{C}_{3} \mathrm{H}_{6}(\mathrm{III})^{*}+\mathrm{O}^{*}\left(\mathrm{O}_{2} *\right) \rightarrow \mathrm{OMMP}_{2} *\left(\mathrm{OOMMP}_{2} *\right)$ & 1.01 & 1.03 & 0.39 & 1.23 & 0.89 & 1.23 \\
\hline M9 OOMMP $_{1} * \rightarrow \mathrm{O}^{*}+\mathrm{OMMP}_{1} *$ & - & - & - & - & -2.22 & 0.51 \\
\hline${\mathrm{M} 10 ~ \mathrm{OOMMP}_{2}}^{*} \rightarrow \mathrm{O}^{*}+\mathrm{OMMP}_{2} *$ & - & - & - & - & -2.64 & 0.38 \\
\hline $\mathrm{M} 11 \mathrm{OMMP}_{1} * \rightarrow \mathrm{PO}_{1} *$ & 0.74 & 1.52 & -1.19 & 0.16 & -0.97 & 0.07 \\
\hline  & -0.26 & 2.17 & -1.65 & 0.37 & -1.48 & 0.24 \\
\hline $\mathrm{M} 13 \mathrm{OMMP}_{2} * \rightarrow \mathrm{PO}_{2} *$ & 0.90 & 1.91 & -0.99 & 0.34 & -0.74 & 0.29 \\
\hline  & -0.29 & 2.52 & -2.00 & 0.57 & -1.95 & 0.75 \\
\hline
\end{tabular}

Table S2. Comparison of activation barriers of each elemental step in propylene reaction on pure and Ru-doped $\mathrm{Cu}_{2} \mathrm{O}(111)^{23}$ (unit: eV)

\begin{tabular}{|c|c|c|c|c|c|c|}
\hline \multirow{2}{*}{ Reaction } & \multicolumn{2}{|c|}{ OsuF } & \multicolumn{2}{|c|}{$\mathbf{O}^{*}$} & \multicolumn{2}{|c|}{$\mathrm{O}_{2}{ }^{*}$} \\
\hline & $\mathrm{Ru} @ \mathrm{Cu}_{2} \mathrm{O}(111)$ & $\mathrm{Cu}_{2} \mathrm{O}(111)$ & $\mathrm{Ru} @ \mathrm{Cu}_{2} \mathrm{O}(111)$ & $\mathrm{Cu}_{2} \mathrm{O}(111)$ & $\mathrm{Ru} @ \mathrm{Cu}_{2} \mathrm{O}(111)$ & $\mathrm{Cu}_{2} \mathrm{O}(111)$ \\
\hline $\mathrm{M} 1 \mathrm{C}_{3} \mathrm{H}_{6}(\mathrm{I})^{*}+\mathrm{O}^{*}\left(\mathrm{O}_{2} *\right) \rightarrow \mathrm{C}_{3} \mathrm{H}_{5} *+\mathrm{OH}^{*}\left(\mathrm{OOH}^{*}\right)$ & 1.75 & 1.20 & 0.99 & 0.82 & 0.88 & 0.92 \\
\hline $\mathrm{M} 2 \mathrm{C}_{3} \mathrm{H}_{5} *+\mathrm{O}_{\text {suF }} * \mathrm{C}_{3} \mathrm{H}_{5} \mathrm{O}_{\text {SuF }} *$ & 0.52 & 1.16 & 0.71 & 0.22 & 0.63 & 0.47 \\
\hline $\mathrm{M} 3 \mathrm{OOH}^{*} \rightarrow \mathrm{O}^{*}+\mathrm{OH}^{*}$ & -- & -- & -- & -- & 0.51 & -- \\
\hline $\mathrm{M} 4 \mathrm{C}_{3} \mathrm{H}_{5} \mathrm{O}_{\mathrm{SUF}} *+\mathrm{OH}^{*} \rightarrow \mathrm{C}_{3} \mathrm{H}_{4} \mathrm{O}_{\mathrm{SUF}} *+\mathrm{H}_{2} \mathrm{O}^{*}$ & -- & -- & 1.33 & 0.74 & 1.20 & 1.33 \\
\hline $\mathrm{M}_{5} \mathrm{C}_{3} \mathrm{H}_{5} \mathrm{O}_{\mathrm{SUF}} *+\mathrm{Ru}^{*} \rightarrow \mathrm{C}_{3} \mathrm{H}_{4} \mathrm{O}_{\mathrm{SUF}} *+\mathrm{RuH}^{*}$ & 1.37 & -- & -- & -- & -- & -- \\
\hline M6 $\mathrm{RuH}^{*}+\mathrm{OH}^{*} \rightarrow \mathrm{Ru}^{*}+\mathrm{H}_{2} \mathrm{O} *$ & 1.00 & -- & -- & -- & -- & -- \\
\hline $\mathrm{M} 7 \mathrm{C}_{3} \mathrm{H}_{6}(\mathrm{II})^{*}+\mathrm{O}^{*}\left(\mathrm{O}_{2} *\right) \rightarrow \mathrm{OMMP}_{1} *\left(\mathrm{OOMMP}_{1} *\right)$ & 1.55 & 1.22 & 1.55 & 1.71 & 1.46 & 1.68 \\
\hline $\mathrm{M} 8 \mathrm{C}_{3} \mathrm{H}_{6}(\mathrm{III})^{*}+\mathrm{O}^{*}\left(\mathrm{O}_{2} *\right) \rightarrow \mathrm{OMMP}_{2} *\left(\mathrm{OOMMP}_{2} *\right)$ & 1.03 & 0.90 & 1.23 & 1.41 & 1.23 & 1.53 \\
\hline $\mathrm{M} 9 \mathrm{OOMMP}_{1} * \rightarrow \mathrm{O}^{*}+\mathrm{OMMP}_{1} *$ & -- & -- & -- & -- & 0.51 & -- \\
\hline $\mathrm{M}_{10} \mathrm{OOMMP}_{2} * \rightarrow \mathrm{O}^{*}+\mathrm{OMMP}_{2} *$ & -- & -- & -- & -- & 0.38 & -- \\
\hline $\mathrm{M} 11 \mathrm{OMMP}_{1} * \rightarrow \mathrm{PO}_{1} *$ & 1.52 & 1.59 & 0.16 & 0.64 & 0.07 & 1.05 \\
\hline $\mathrm{M}_{12} \mathrm{OMMP}_{1} * \rightarrow \mathrm{PA}^{*}$ & 2.17 & 2.21 & 0.37 & 0.23 & 0.24 & 0.63 \\
\hline $\mathrm{M} 13 \mathrm{OMMP}_{2} * \rightarrow \mathrm{PO}_{2} *$ & 1.91 & 1.92 & 0.34 & 0.28 & 0.29 & 0.44 \\
\hline $\mathrm{M} 14 \mathrm{OMMP}_{2} * \rightarrow \mathrm{AC}^{*}$ & 2.52 & 2.02 & 0.57 & 0.43 & 0.75 & 0.40 \\
\hline
\end{tabular}


Table S3. Adsorption energy of the key species of propylene reaction on $\mathrm{Ru}_{0} \mathrm{Cu}_{2} \mathrm{O}(111)$ and $\mathrm{Cu}_{2} \mathrm{O}(111)$ without van der Waals correction(unit: $\mathrm{eV}$ )

\begin{tabular}{cccccccc}
\hline Species & $\mathbf{C}_{\mathbf{3}} \mathbf{H}_{\mathbf{6}}$ & $\mathbf{O M M P}_{\mathbf{1}}$ & $\mathbf{O M M P}_{\mathbf{2}}$ & acrolein & PO & propanal & acetone \\
\hline $\mathrm{Ru} @ \mathrm{Cu}_{2} \mathrm{O}(111)$ & -1.09 & 1.31 & -1.43 & -0.580 & -0.67 & -0.19 & -0.66 \\
$\mathrm{Cu}_{2} \mathrm{O}(111)$ & -0.75 & 1.12 & -1.16 & -0.608 & -0.36 & -0.38 & -0.83 \\
\hline
\end{tabular}

Note: $E_{\text {ads }(\mathrm{OMMP})}=E_{(\text {OMMP })}-E_{\left(\mathrm{C}_{3} \mathrm{H}_{6}\right)}-1 / 2 E_{\left(\mathrm{O}_{2}\right)}-E_{(\text {cata })}$.

Table S4. The entropy contribution values of adsorbates when adsorb on $\mathrm{Ru} @ \mathrm{Cu}_{2} \mathrm{O}(111)$ (unit: eV)

\begin{tabular}{ccccccc}
\hline Adsorbates & $\mathbf{C}_{\mathbf{3}} \mathbf{H}_{\mathbf{6}}$ & $\mathbf{O}_{\mathbf{2}}$ & acrolein & PO & propanal & acetone \\
\hline entropy contribution values & -0.62 & -0.48 & -0.57 & -0.58 & -0.60 & -0.61 \\
\hline
\end{tabular}




\section{References:}

1. Kresse, G.; Furthmüller, J., Efficiency of Ab-Initio Total Energy Calculations for Metals and Semiconductors Using a Plane-Wave Basis Set. Computational Materials Science 1996, 6, 15-50.

2. Kresse, G.; Furthmüller, J., Efficient Iterative Schemes for Ab Initio Total-Energy Calculations Using a Plane-Wave Basis Set. Physical Review B 1996, 54, 11169.

3. Perdew, J. P.; Burke, K.; Ernzerhof, M., Generalized Gradient Approximation Made Simple. Physical Review Letter 1996, 77, 3865 .

4. Ernzerhof, M.; Scuseria, G. E., Assessment of the Perdew-Burke-Ernzerhof Exchange-Correlation Functional. The Journal of Chemical Physics 1999, 110, 5029-5036.

5. Kresse, G.; Joubert, D., From Ultrasoft Pseudopotentials to the Projector Augmented-Wave Method. Physical Review B 1999, 59, 1758 .

6. Blöchl, P. E., Projector Augmented-Wave Method. Physical review B 1994, 50, 17953.

7. Blöchl, P. E.; Först, C. J.; Schimpl, J., Projector Augmented Wave Method: Ab Initio Molecular Dynamics with Full Wave Functions. Bulletin Materials Science 2003, 26, 33-41.

8. Monkhorst, H. J.; Pack, J. D., Special Points for Brillouin-Zone Integrations. Physical review B 1976, $13,5188$.

9. Pack, J. D.; Monkhorst, H. J., "Special Points for Brillouin-Zone Integrations"—a Reply. Physical Review B 1977, 16 , 1748.

10. Liechtenstein, A.; Anisimov, V.; Zaanen, J., Density-Functional Theory and Strong Interactions: Orbital Ordering in Mott-Hubbard Insulators. Physical Review B 1995, 52, R5467.

11. Wu, D.; Zhang, Q.; Tao, M., LSDA+U Study of Cupric Oxide: Electronic Structure and Native Point Defects. Physical Review B 2006, 73, 235206.

12. Bendavid, L. I.; Carter, E. A., $\mathrm{CO}_{2}$ Adsorption on $\mathrm{Cu}_{2} \mathrm{O}(111)$ : A DFT+U and DFT-D Study. The Journal of Physical Chemistry C 2013, 117, 26048-26059.

13. Yu, K.; Carter, E. A., Communication: Comparing Ab Initio Methods of Obtaining Effective U Parameters for ClosedShell Materials. Journal of Chemical Physics 2014. 140, 121105-121110.

14. Mosey, N. J.; Liao, P.; Carter, E. A., Rotationally Invariant Ab Initio Evaluation of Coulomb and Exchange Parameters for DFT+ U Calculations. The Journal of Chemical Physics 2008, 129, 014103.

15. Henkelman, G.; Jónsson, H., Improved Tangent Estimate in the Nudged Elastic Band Method for Finding Minimum Energy Paths and Saddle Points. The Journal of Chemical Physics 2000, 113, 9978-9985.

16. Grimme, S.; Ehrlich, S.; Goerigk, L., Effect of the Damping Function in Dispersion Corrected Density Functional Theory. Journal of Computational Chemistry 2011, 32, 1456-1465.

17. Restori, R.; Schwarzenbach, D., Charge Density in Cuprite, $\mathrm{Cu}_{2} \mathrm{O}$. Acta Crystallographica Section B: Structural Science 1986, 42, 201-208.

18. Werner, A.; Hochheimer, H., High-Pressure X-Ray Study of $\mathrm{Cu}_{2} \mathrm{O}$ and $\mathrm{Ag}_{2} \mathrm{O}$. Physical Review B 1982, $25,5929$.

19. Long, W.; Zhai, Q.; He, J.; Zhang, Q.; Deng, W.; Wang, Y., Significant Synergistic Effect between Supported Ruthenium and Copper Oxides for Propylene Epoxidation by Oxygen. ChemPlusChem 2012, 77, 27-30.

20. Li, R. -S.; Ma, D. -L.; Wang, G. -C.; Density functional theoretical study of $\mathrm{O}_{2}$ dissociation on $\mathrm{Cu}_{2} \mathrm{O}(111)$ : $\mathrm{Ru}$ effect. Science Sinica Chimica 2019, 49, 1-9.

21. Haynes, W. M., Crc Handbook of Chemistry and Physics; CRC Press, 2014.

22. Roldan, A.; Gonzalez, S.; Ricart, J. M.; Illas, F., Critical Size for $\mathrm{O}_{2}$ Dissociation by Au Nanoparticles. Chemphyschem 2009, 10, 348-51.

23. Song, Y.-Y.; Wang, G.-C., Theoretical Study of Propylene Epoxidation over $\mathrm{Cu}_{2} \mathrm{O}(111)$ Surface: Activity of $\mathrm{O}^{2-}$, $\mathrm{O}^{-}$, and $\mathrm{O}^{2-}$ Species. The Journal of Physical Chemistry C 2018, 122, 21500-21513. 